\title{
Interpretation of Aeromagnetic Data on the Area around Aswan-Berenice Road, Southeast Aswan, Egypt
}

\author{
Karrar Omar El-Faragawy \\ Faculty of Science, Aswan University, Aswan, Egypt \\ Email:karrar04@yahoo.com
}

How to cite this paper: El-Faragawy, K.O. (2016) Interpretation of Aeromagnetic Data on the Area around Aswan-Berenice Road, Southeast Aswan, Egypt. Open Journal of Geology, 6, 1196-1207.

http://dx.doi.org/10.4236/ojg.2016.69088

Received: August 16, 2016

Accepted: September 25, 2016

Published: September 28, 2016

Copyright $\odot 2016$ by author and Scientific Research Publishing Inc. This work is licensed under the Creative Commons Attribution International License (CC BY 4.0).

http://creativecommons.org/licenses/by/4.0/ (c) (i) Open Access

\begin{abstract}
The area around Aswan-Berenice Road southeast Aswan is geophysically studied to delineate the subsurface structures and to evaluate the tectonic framework of the basement rocks and the overlying sedimentary cover. This area comprises a variety of igneous, metamorphic and sedimentary rocks, ranging in age from Precambrian to Quaternary time. The interpretation of the aeromagnetic data around Aswan-Berenice Road was carried out using GM-SYS modeling technique. Many methods were performed to the RTP aeromagnetic map of the study area such as filtering and trend analysis techniques. The tracing upward and downward of the deduced subsurface structures was investigated using trend analysis for the surface geology and filtered magnetic maps. The locating and determination of the approximate depth of the causative bodies were done using Euler deconvolution, Werner deconvolution and 2.5 dimension magnetic modeling techniques. The obtained results indicate that the most significant tectonic trends are N-S and E-W, which they are in accordance with the local trends of River Nile and Kalabsha fault respectively. Less common trends as NW-SE and NE-SW directions are also detected. Also, the depth to the basement rocks ranges from $0 \mathrm{~km}$ at the exposed parts to $1.4 \mathrm{~km}$ at the covered parts.
\end{abstract}

\section{Keywords}

Aeromagnetic Data, RTP, Residual, El-Hudi, Aswan

\section{Introduction}

The study area lies in Upper Egypt, between latitudes $23^{\circ} 30^{\prime} \mathrm{N}$ to $24^{\circ} 00^{\prime} \mathrm{N}$ and longitudes $33^{\circ} 00^{\prime} \mathrm{E}$ to $33^{\circ} 45^{\prime} \mathrm{E}$. It covers about 3750 square kilometers. The study area lies in the Southeastern Desert, Southeast of Aswan province as shown in location map 
(Figure 1(a)). The study area lies to the east of Aswan. Aswan-Berenice road is passing through the study area. Many Wadies are distributed through the study area; among those are Wadi El-Hudi and Wadi Arab. Jabal El Hudi, Jabal Ajyp and Jabal Barqat Tukham are the main mountains in the study area. The study area is considered of great importance for ornamental stones and mineral resources, due to the presence of

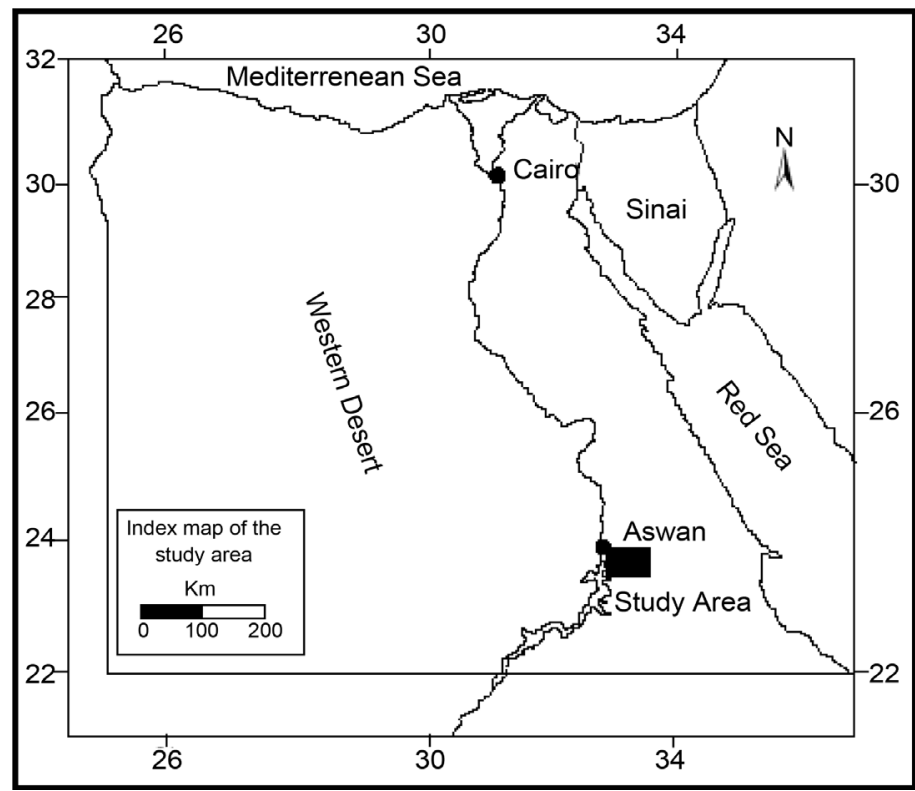

(a)

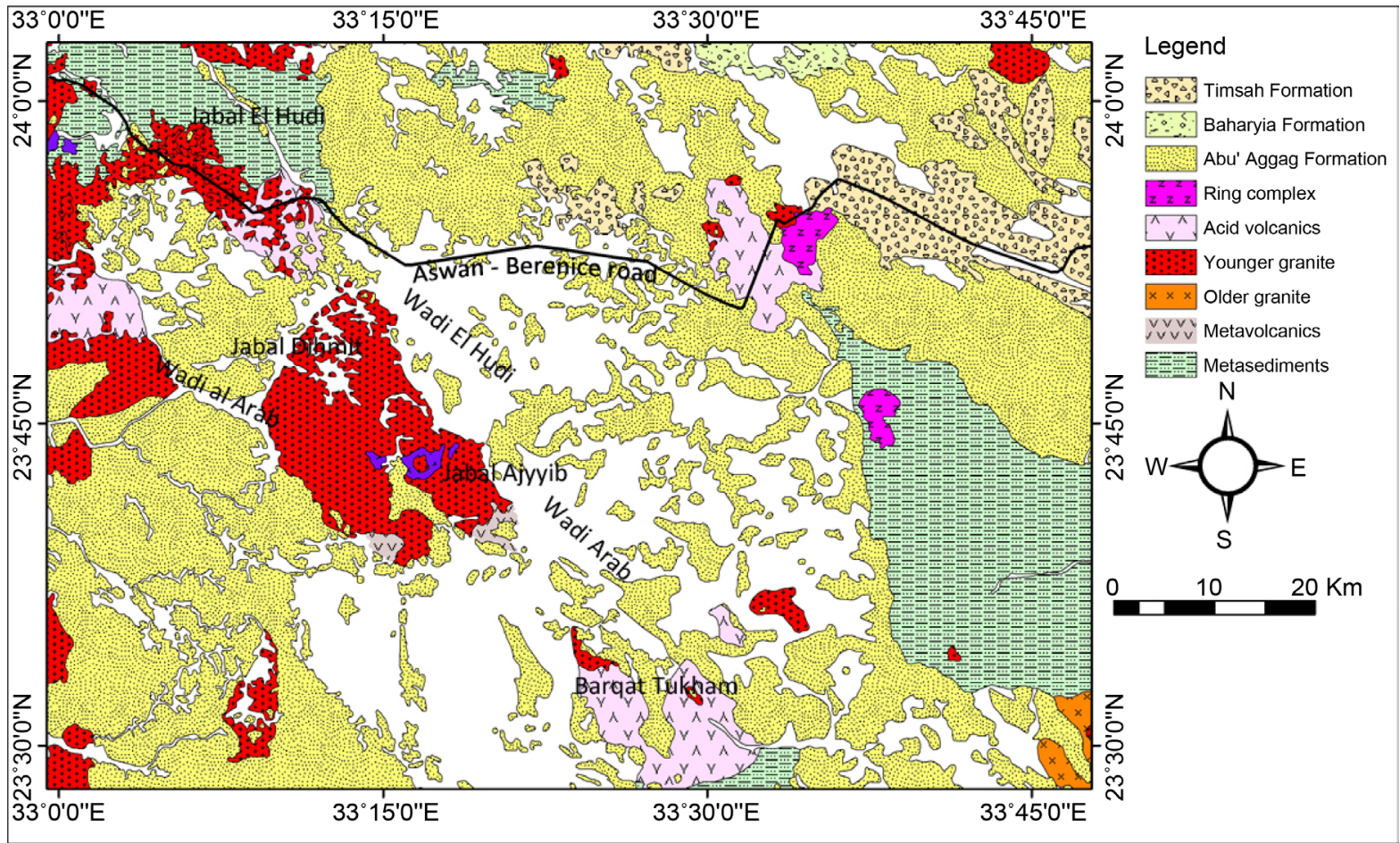

(b)

Figure 1. (a) Location map of the study area, (b) Geological map of the study area (after EGSMA, 1996). 
many occurrences of economic ores.

The present study is carried out to evaluate the subsurface structures and tectonic framework of the basement rocks, and to analyze the different tectonic events that affected the area. The available magnetic data are reduced to the pole (RTP) aeromagnetic map (Figure 2). This map was prepared by the Western Geophysical Company of America for the Egyptian General Petroleum Corporation [1]. It was acquired at a flight elevation of 120 meters and flight line spacing of $1.0 \mathrm{~km}$. The RTP aeromagnetic anomaly map is provided with a scale 1:50,000.

\section{Geological Setting}

Several pioneers have previously studied the geology of the area. Among those are; [2]-[9].

From the geologic map (Figure 1(b)) which is reproduced after the Egyptian Geological Survey and Mining Authority [6], we conclude that, the geology of the study area is made of a thick sedimentary section of Nubia Formation of Late Cretaceous age, that overly the Precambrian basement. The basement rocks are cropping out in some parts and near to earth's surface in other parts of the study area.

The exposed basement rocks are including metamorphic and igneous units. The metamorphic rocks include the oldest deformed rock units in the area. The exposed igneous rocks in the study area are mostly of granitoid composition. Quaternary represented by alluvial deposits covering the distributed wadies in the study area. The study area is affected by surface faults trending in the N-S, E-W, NW-SE and NE-SW directions.

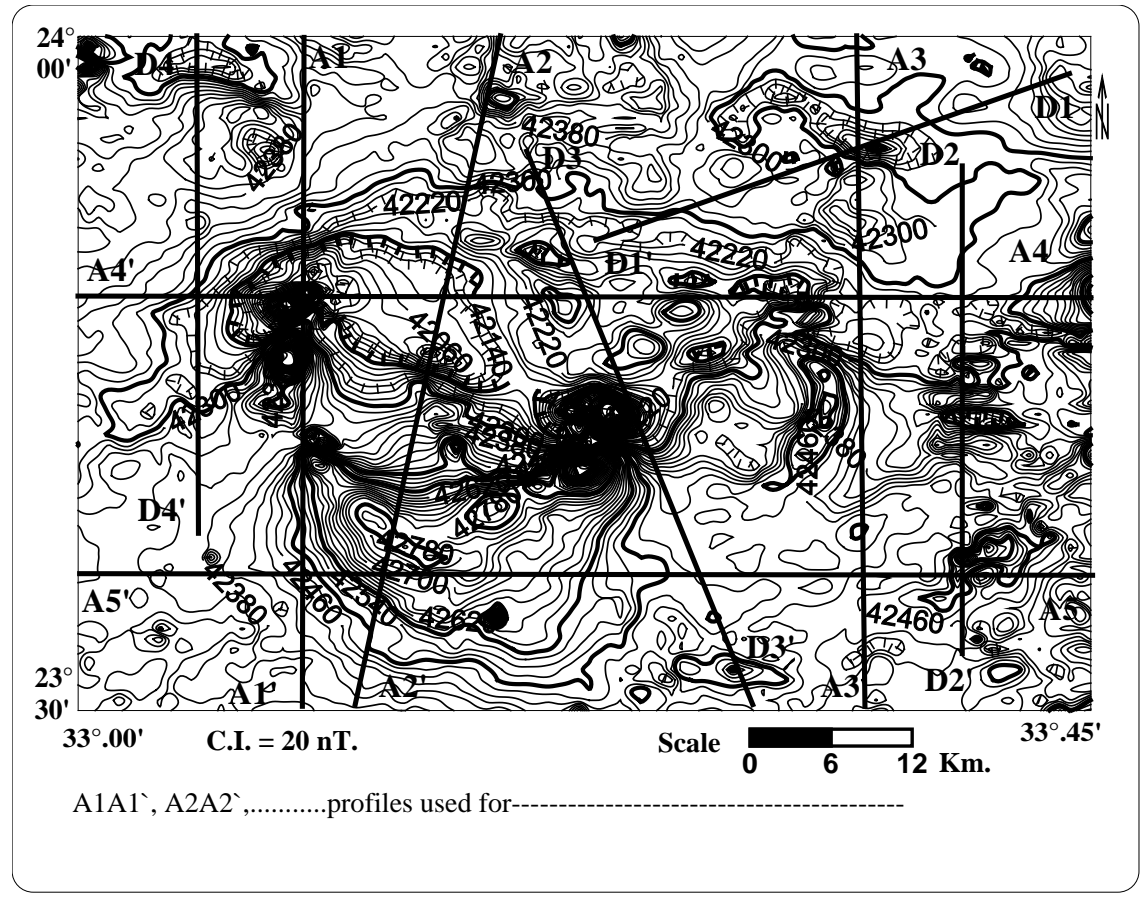

Figure 2. RTP aeromagnitic map of the study area. 


\section{Magnetic Data Analysis}

The Reduced to the pole aeromagnetic map of the area (Figure 2) has been digitized into rectangular grid format to be suitable for processing. Thereafter, and in order to assist in the delineation of structure and lithologic variations, a number of processing operations has been performed on the grid data using Fourier transform algorithms [10] to produce some enhanced by-products which include:

1) Filter techniques that include high, band and low-pass filters in order to recognize the shallow and deep sources responsible for the residual and regional fields.

2) Trend analysis were carried out on the RTP, residual and regional maps in order to define the major surface and subsurface tectonic trends that affect the study area.

3) Depth estimation was carried out for the major anomalies present on the RTP magnetic map through selected profiles crossing those anomalies, in order to delineate the structural relief of the basement surface and the structural deformation of the overlying sedimentary layers. The used methods for the depth estimation are Werner deconvolution, two and half dimensional modelling and Euler deconvolution methods.

\subsection{Reduction to the Pole (RTP) Aeromagnetic Map}

The inspection of the RTP aeromagnetic map (Figure 2) indicates that most of the magnetic anomalies trend in the NE-SW, NW-SE, N-S and E-W directions. This is due the effect of opening the Gulf of Suez, Red Sea and Syrian Arc system tectonic forces. One can also verify the presence of steep gradients separating magnetic high from magnetic low anomalies at the middle part of the area. Also, two major irregular anomalies can be noticed at the south-western part of the study area.

The presence of N-S trends in the RTP aeromagnetic map is attributed to a limited and local tectonic force similar to that causing the north south direction of the River Nile to the west of the study area. Minor anomalies take the E-W trend and they can be attributed to the presence of lithofacies changes. The magnetic low anomalies at northeast and southwest parts of the map may be due to its relative deep depths or different rock polarities. The magnetic anomalies trends are correlated with the shallow geologic structures constructed by Hunting Geology and Geophysics LTD, [11], (Figure 3).

\subsection{Filtering}

The main target of filtering techniques is the separation of anomalies of different wavelength, which can be attributed to heterogeneity of magnetic properties at different depths (Spector, and Grant, 1970). In the present study the filtering technique developed by Zurflueh [12] were applied to the RTP magnetic data. Results are shown in Figure 4. High pass filter, band pass and low pass filtered data (with 2.7, 4 and 5.3 unit filter).

The anomalies of the residual filtered map have E-W, NE-SW, NW-SE and N-S directions. Their small sizes and steep gradients indicate their shallow origin. While these anomalies become of intermediate sizes, gradients at the band-pass filtered map and they are taking the N-S direction as main trend. The regional filtered map shows large 


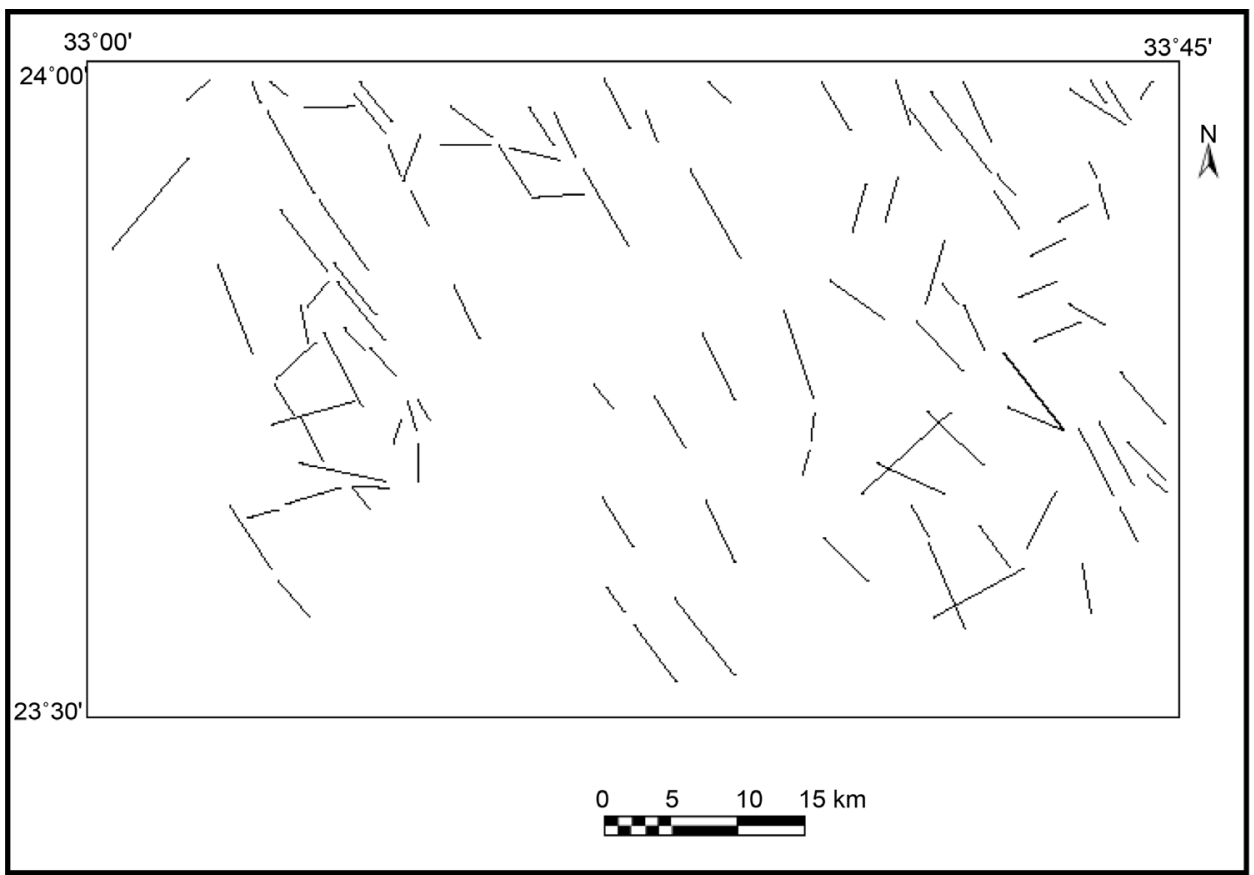

Figure 3. Structural lineament map of the study area, (after Hunting Geology and Geophysics LTD 1967).

size anomalies with gentle gradients, and they have the E-W trend as major trend of the deep-seated structures.

\section{Trend Analysis}

To delineate the subsurface fault trends based on the theory of Grant \& West [13] and on the Linsser technique [14], the 1st horizontal gradient method was applied to RTP magnetic map. The peaks of the gradient curve were plotted along profiles covering that map and connected together to show the deduced structure lines. The different fault directions were then grouped into segments of $10^{\circ}$ of azimuth each. These groups are represented according to the tectonic movements that prevailed in the studied area. The structures of the RTP aeromagnetic map were traced downward along the filtered aeromagnetic maps (Figure 5(a)). These structure trends were represented by rose diagrams (Figure 5(b)).

The results indicate that the most significant tectonic trend is the N-S, because it is in accordance with the River Nile direction to the west of the study area, followed by the $\mathrm{E}-\mathrm{W}$ direction, it is also coincide with the direction of the faults at the western bank of the River Nile, as the famous Kalabsha fault which trends E-W. The E-W trend has been interpreted by Youssef [15] as an ancient fracture system resulting from a northern compressive force. Meshref [16] stated that the thrusting or uplifting of the African continent against the main block of the earth's crust might have been the cause of the formation of the E-W (Mediterranean) trending swells and thrusts across the northern part of Africa continent, including Egypt. These trends are extended from deep depths to shallow surface rocks. The less significant directions are NW-SE (related to Gulf of 


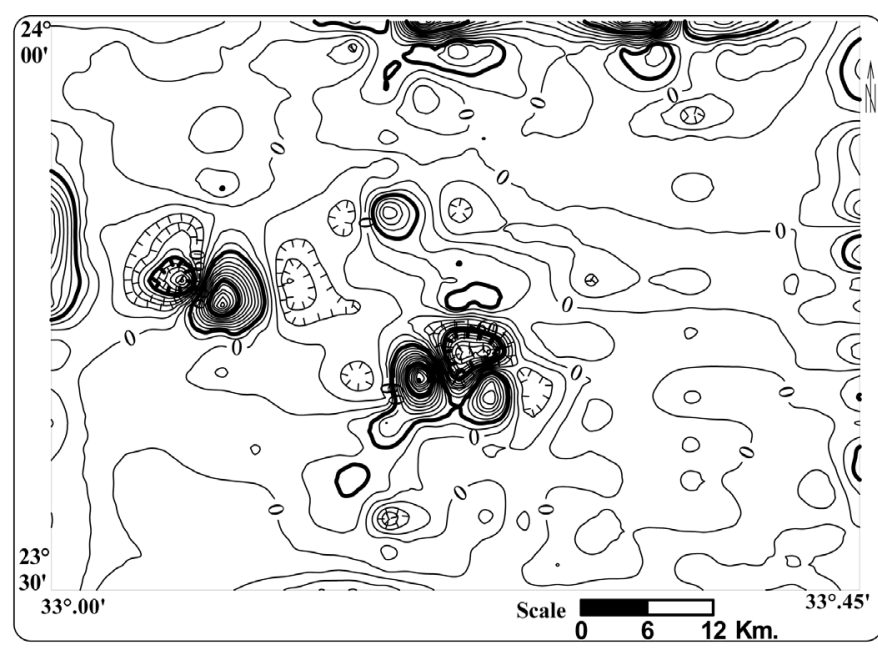

(a)

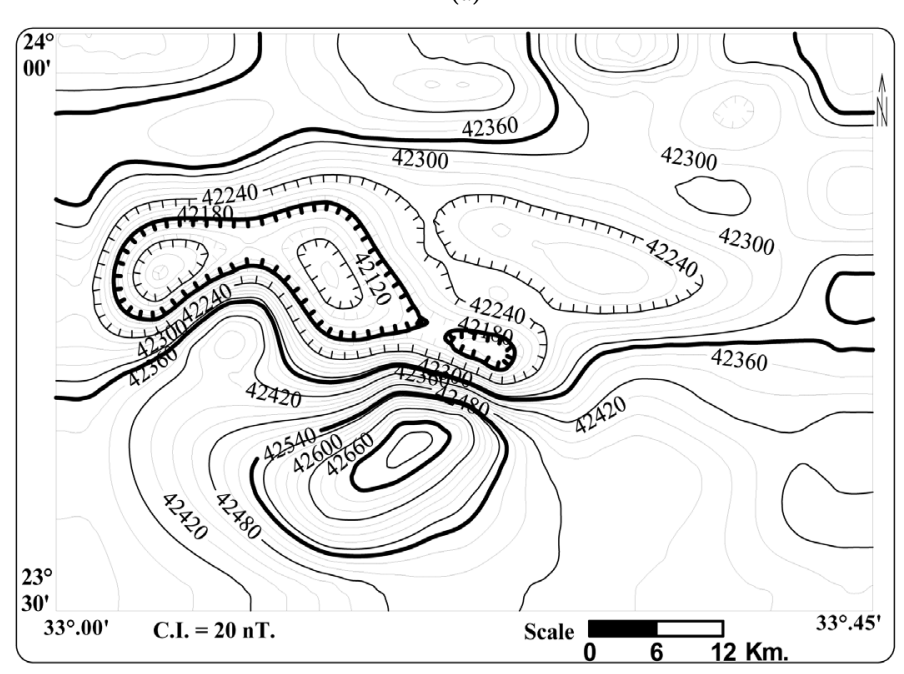

(c)

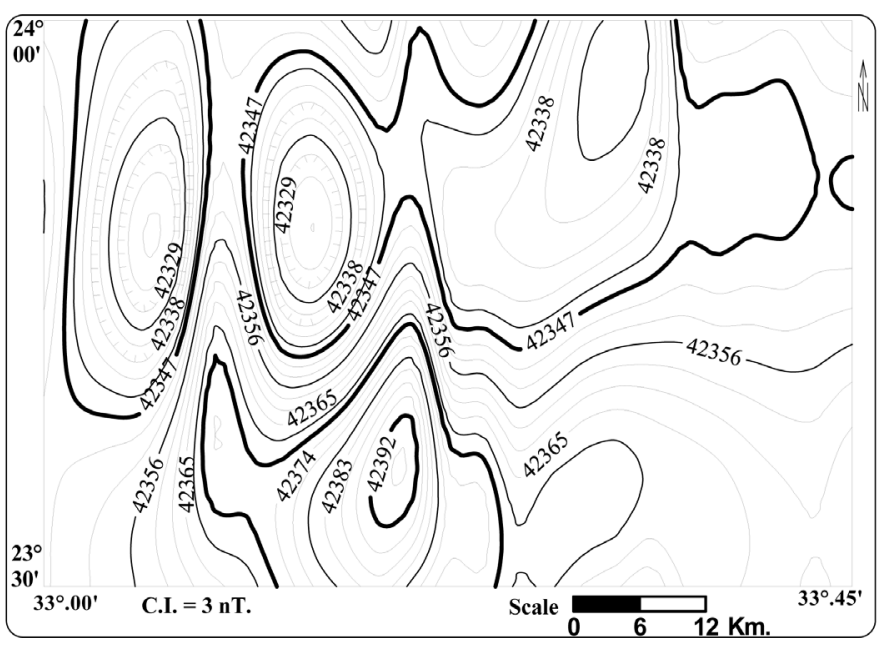

(b)

Figure 4. Filtered aeromagnetic maps: (a) High-pass filtered map, (b) Band-pass filtered map, and (c) Low-pass filtered map.

Suez and Red Sea tectonics), followed by (NE-SW) representing Syrian Arc trend, that related to the tectonic force extends form Syria in the north passes through dead sea and Jordon depression, Sinai, and ending at the Western Desert of Egypt ([15]-[19]).

\section{Depth Estimation}

\subsection{Werner Analysis Technique}

Werner [20] method's principle is to select a group of four or more measurements and to calculate the location of the magnetic body separately. When locations are plotted in cross sections, the depth estimates tend to cluster around the true location of the causative body. $\mathrm{Ku}$ and Sharp [21] considered a dike with infinite strike length and depth extent. This technique allows computing depths to the magnetic bodies with high efficiency. The depth to the basement as obtained from the RTP map (Figure 6) range from about 200 meters to about 1300 meters. 


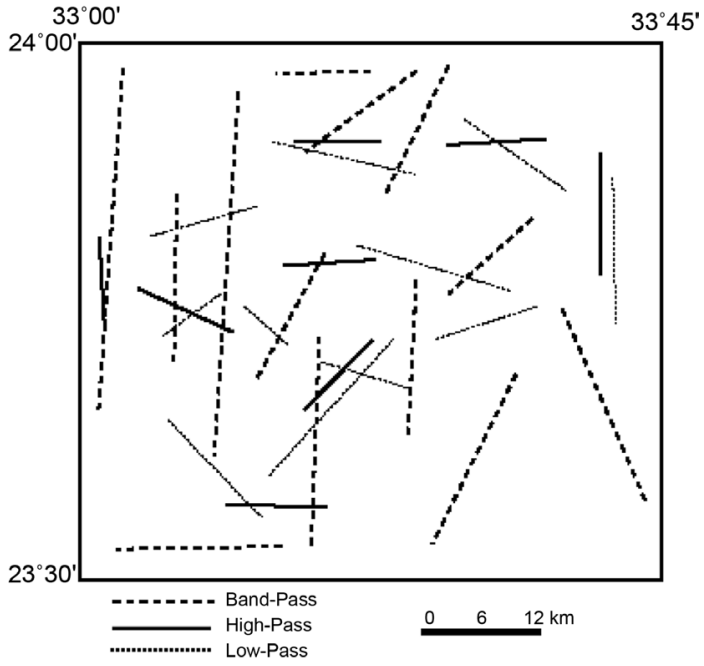

(a)

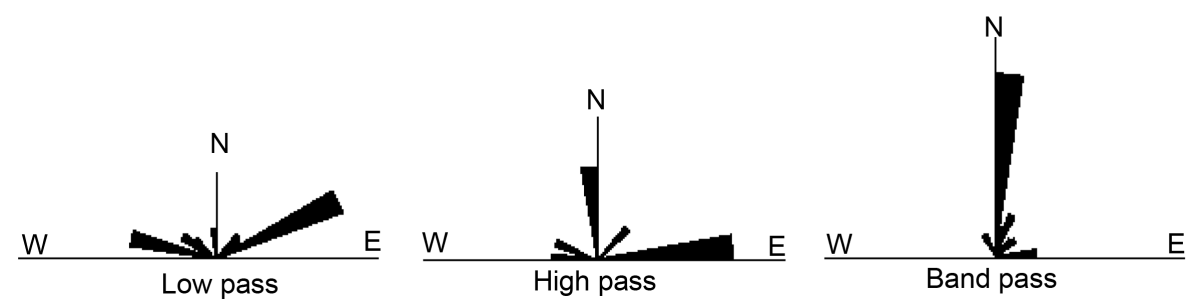

(b)

Figure 5. (a) Structural map as deduced from filtered aeromagnetic maps, (b) Rose diagrams show the prevailed tectonic trends of these structures.

\subsection{Two and Half Dimensional Modelling Method}

The two and half dimensional modelling method after $\mathrm{Ku}$, [22] is applied to the RTP map of the study area. Computations of the magnetic effects by models with complex geometry have been carried out using the GM-SYS [23] computer program for arbitrary two-dimensional polygons. Several magnetic profiles were selected to perform such computations, covering most of the study area (Figure 2). It is obvious that the depth to the basement on the regional scale increases towards the north part of the study area. The average depth to the basement rocks ranges from 100 meters to about $1.3 \mathrm{Km}$ (Figure 7 and Figure 8).

Moreover Table 1 shows the magnetic susceptibility deduced from the application of the two and half dimensions methods along the applied profiles.

\subsection{Euler Deconvolution Method}

The interpretation of structural elements specially fault zones from magnetic data is generally based on linear features identified on image-based products using colour and shaded relief presentations. It is often difficult to assess the degree of continuity of the specific structures and their relative contribution to the observed magnetic anomaly. The Euler deconvolution method [24] serves to determine source positions and the depths of the geomagnetic inhomogeneities. 


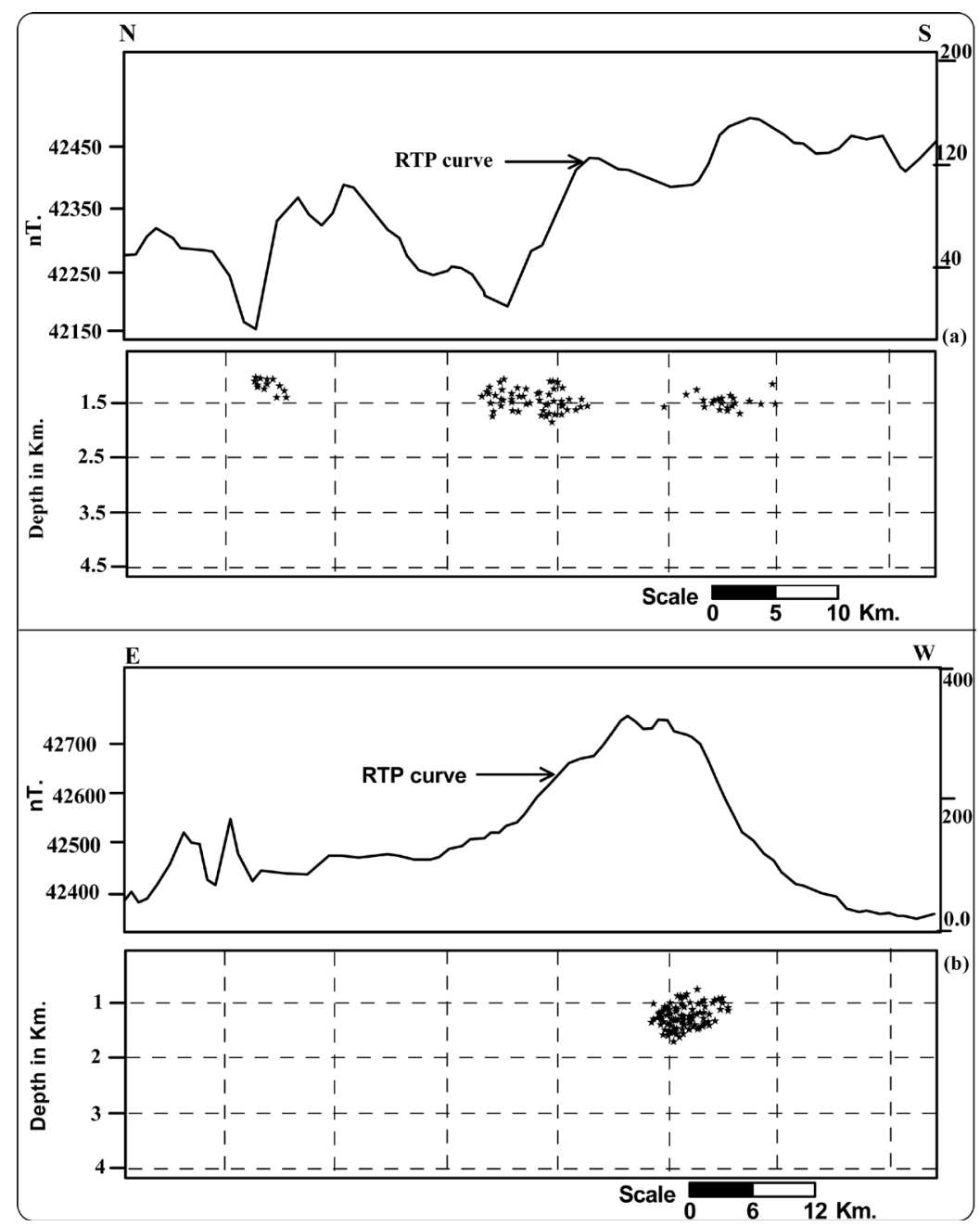

Figure 6. Application of Werner deconvolution method along: (a) M1-M1' and (b) M4-M4' of the aeromagnetic maps.

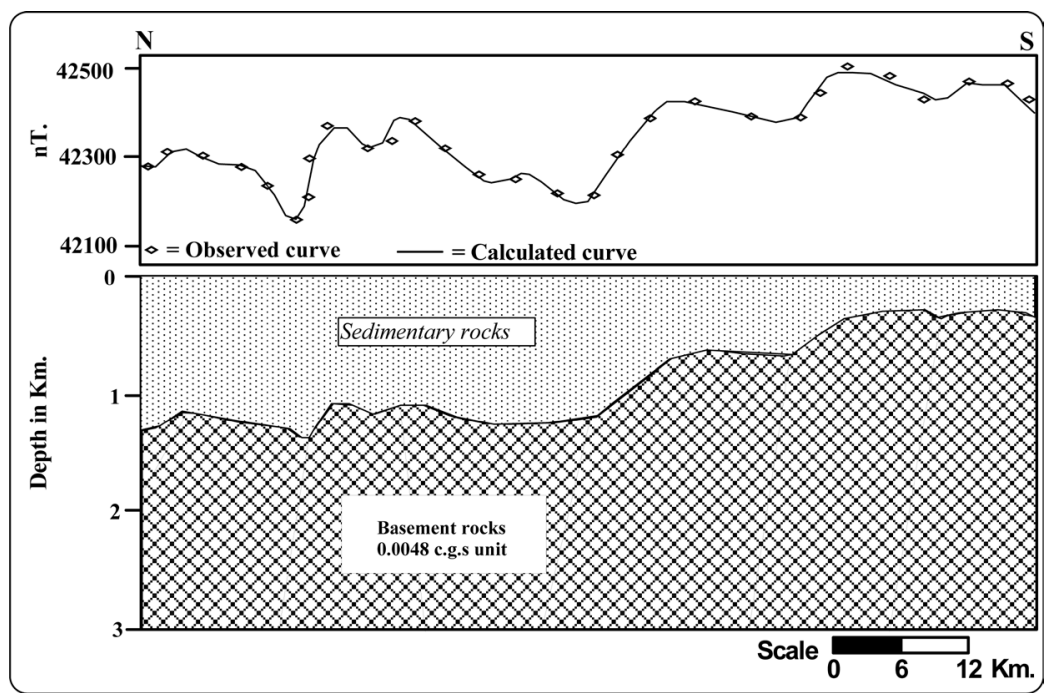

Figure 7. 2.5 Dimensional magnetic model along A3-A3' of the RTP magnetic map. 


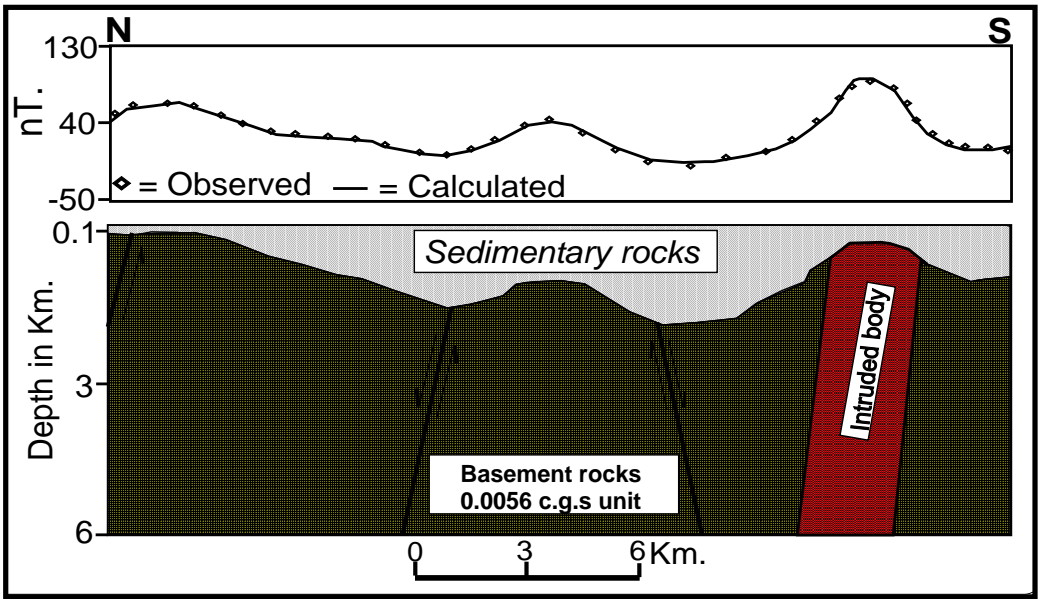

Figure 8. 2.5 Dimensional magnetic model along A1-A1' of the RTP magnetic map.

Table 1. Magnetic susceptibilities deduced from the application of 2.5 dimensional modelling method.

\begin{tabular}{ccc}
\hline Profiles & Magnetic susceptibility in c. g. s. units & Average \\
\hline A1-A1' & 0.0051 & \\
A2-A2' & 0.0059 & \\
A3-A3' & 0.0056 & $(0.0059-0.0048)$ \\
D1-D1' & 0.0048 & \\
D2-D2' & 0.0053 & \\
D3-D3' & 0.0050 & \\
\hline
\end{tabular}

This technique is applied to the grided data, which can measure the gradients, locate the square windows within the grids of gradient values and field, and locate the structural windows. The results are plotted in its plane $(\mathrm{x}, \mathrm{y})$ position using a symbol size proportional to depth $\mathrm{z}$.

Euler deconvolution method was applied to the vertical gradient of the total magnetic field [25] \& [26] along a set of profiles covering the RTP aeromagnetic map. The results show that the average depths range between 0 and about $1.4 \mathrm{~km}$ (Figure 9 and Figure 10).

\section{Summary and Conclusions}

1) The study area represents a part of the south Egypt with low relief within the Precambrian basement rocks that is covered by sedimentary rocks.

2) The most significant tectonic trend affecting the study area is N-S, which reflects the direction of the River Nile to the west of the study area. This tectonic trend is continued upward from the deeper depths to the shallow surface sedimentary rocks. The second in importance is the E-W trend, which is in accordance with the fault system present in the western bank of the River Nile, as Kalabsha famous fault. It is related to the Mediterranean (Tethyan) trend. This trend is observed at deep depths. The third in 


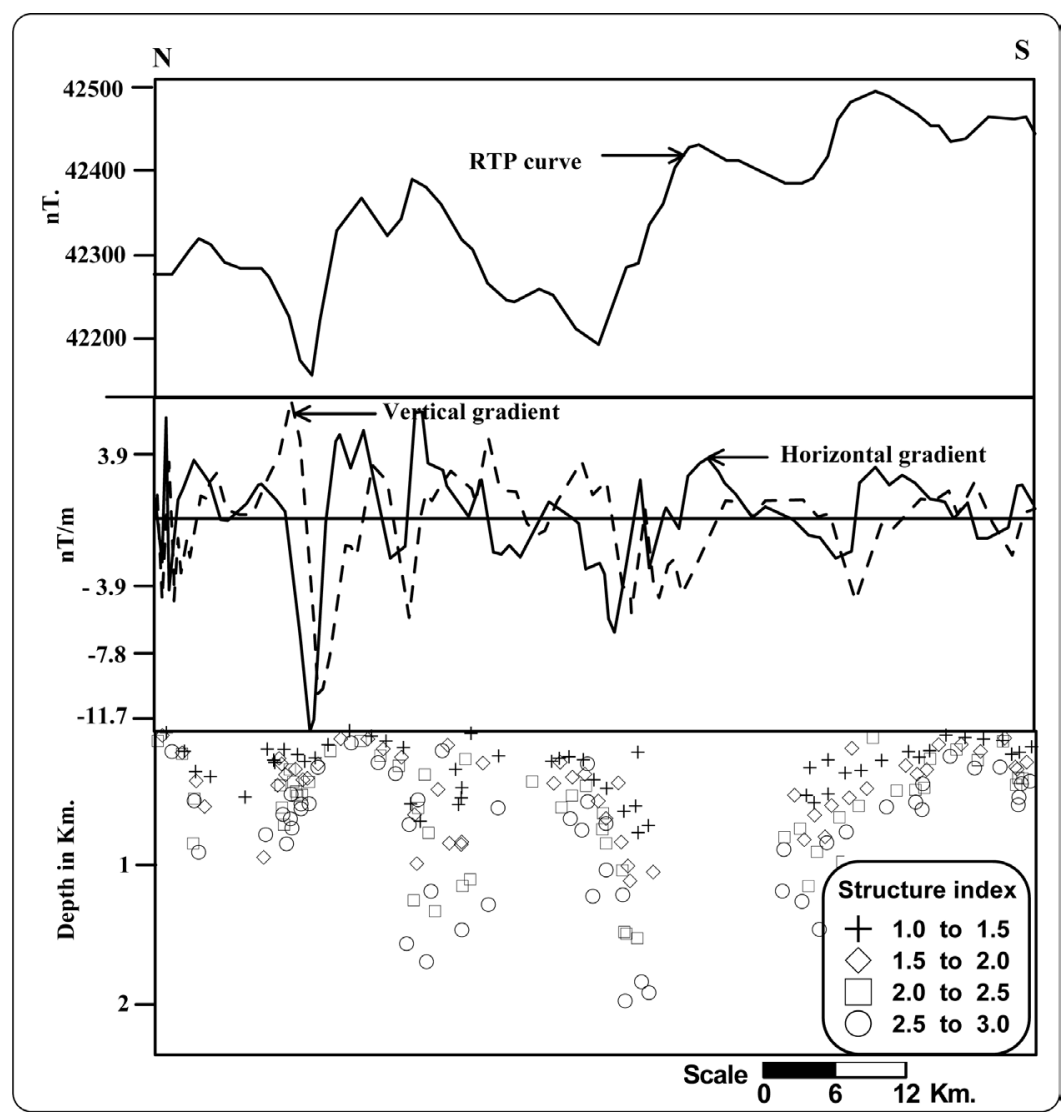

Figure 9. Application of Euler deconvolution along profile A3-A3' to the aeromagnetic anomaly map.

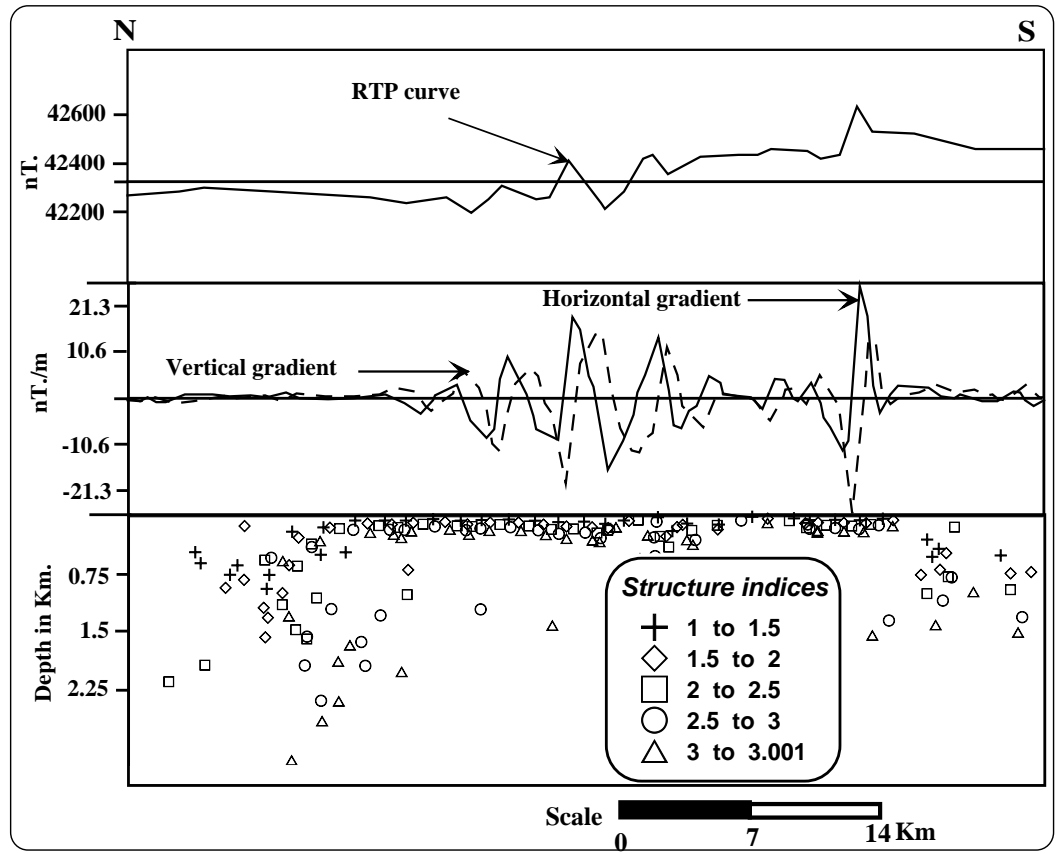

Figure 10. Application of Euler deconvolution along profile D2-D2' to the aeromagnetic anomaly map. 
importance is the NW-SE, which reflects the orientation of the Gulf of Suez and the Red Sea fault system. This tectonic trend is continued upward from the deeper depths to the shallow depths sedimentary rocks. The less common trend is the NE-SW trend, which represents the intraplate fold belt of the Syrian Arc System in Egypt.

3) Wadies in the study area seemed to take the trend of the regional structure of Egypt. Wadi al-Hudi and Wadi arab in the central part of the area have the direction of Gulf of Suez (NW-SE), while Wadi Hair al-Quffah in the southern part of the study area has the E-W direction (Tethyan).

4) Depth to the basement rocks computed using Werner, and Euler deconvolution methods indicates consistently a main depth to the basement ranging between $0 \mathrm{~km}$ and $1.4 \mathrm{~km}$. The greatest depth is appearing in the northern part, wheras the shallow depths belong to the western and southern parts of the study area since the basement rocks are found near the earth's surface or cropping out to the surface. On the other hand, the analysis of the 2.5-D model along a set of magnetic profiles across the different structural units indicates that the general dipping of the basement rocks is towards the northern part of the study area. The main depths to the basement rocks range between $0 \mathrm{~km}$ for the exposed basement rocks and $1.3 \mathrm{~km}$ for the buried units.

Finally, the results obtained from this study can be used as a guide to understand the structural framework of the area and for future mineral explorations.

\section{References}

[1] Aero Service (1983) RTP Aeromagnetic Map, Scale 1:50,000, Sheets No. 87 \& 88, Project No. 105, Prepared by the Western Geophysical Company of America for the Egyptian General Petroleum Corporation (EGPC), Unpublished.

[2] Issawi, B. (1968) The Geology of Kurkur-Dungle Area: Geological Survey, Egypt, Paper No. $46,102 \mathrm{p}$.

[3] El Shazly, E.M., Abdel Hady, M.A., El Ghawaby, M.A. and El Kassas, I.A. (1974) Geologic Interpretation of ERTS-1 Satellite Images for West Aswan Area, Egypt. Proceedings of the 9th International Symposium on Remote Sensing of Environment, Arbor, 15-19 April 1974, 119-131.

[4] El Shazly, E.M., Abdel Hady, M.A., El Kassas, I.A., Salman, A.B., El Shazly, M.M., El Amin, H. and Abdel Megid, A.A. (1976) Geology of Kharga-Dakhla Oasis Area, Western Desert, Egypt, from NASA Land Sat.1 Satellite Images; Remote Sensing Research Project, Academy of Scientific Research and Technology, Cairo, $41 \mathrm{p}$.

[5] EGSMA (1978) Geological Map of Aswan Quadrangle, Egypt Scale 1:500,000, EGSMA, Ministry of Industry and Mineral Resources, Cairo.

[6] EGSMA (1996) Geologic Map of Jabal Hadaiyb Quadrangle, Egypt, Scale 1:250000.

[7] Van Houten, F.B. and Bhattacharyya, D.P. (1979) Late Cretaceous Nubia Formation at Aswan, South Eastern Desert, Egypt. Annals of the Geological Survey of Egypt, 9, 408-431.

[8] Klitzch, E. and Wycisk, P. (1987) Geology of the Sedimentary Basins of Northern Sudan and Bordering Areas. Berliner Geowiss. Abh. $(A), 75,97-136$.

[9] Hendriks, F., Luger, P., Bowtiz, J. and Kallenbach, H. (1987) Evolution of the Depositional Environments of SE-Egypt during the Cretaceous and Lower Tertiary. Berliner Geowiss. Abh. (A), 75, 49-82. 
[10] Spector, A. and Grant, F.S. (1970) Statistical Models for Interpretating Aeromagnetic Data. Geophysics, 35, 293-302. http://dx.doi.org/10.1190/1.1440092

[11] Hunting Geology and Geophysics LTD (1967) Assessment of the Minerals Potential of Aswan Region, U.A.R. Unpublished Report. Hunting Geology and Geophysics LTD., England, UNDP and U.A.R. Regional Planning of Aswan, 138 p.

[12] Zurflueh, E.G. (1967) Application of Two-Dimensional Linear Wavelength Filtering. Geophys, 32, 1015-1035. http://dx.doi.org/10.1190/1.1439905

[13] Grant, F.S. and West, G.F. (1965) Interpretation Theory in Applied Geophysics. MacGrawHill, $583 \mathrm{p}$.

[14] Linsser, H. (1967) Investigation of Tectonic by Gravity Detailing. Geophysical Prospecting, 15, 480-515. http://dx.doi.org/10.1111/j.1365-2478.1967.tb01800.x

[15] Youssef, M.I. (1968) Structural Pattern of Egypt and Its Interpretation. AAPG Bulletin, 52, 601-614.

[16] Meshref, W. (1990) Tectonic Framework of Egypt. In: Said, R., Ed., Geology of Egypt, Balkema/Rotterdam/Bookfield, Netherlands, 113-156.

[17] Ghanem, M. (1968) The Geology of Wadi Kareim Area, Eastern Desert, Egypt. Unpublished PhD Thesis, Cairo University, Giza.

[18] Ammar, A.A., Fouad, K.M. and Meleik, M.L. (1983) Tectonic Analysis of a Sample Area, Central Eastern Desert, Egypt, Applying Aeroradiometric and Aeromagnetic Survey Data. Journal of King Abdulaziz University, 6, 459-482.

[19] Abu El-Ata, A.M. (1988) The Relation between the Local Tectonics of Egypt and Plate Tectonics of the Surrounding Regions, Using Geophysical and Geological Data. EGS Proceedings of the 6 th Annual Meeting, Cairo, 92-112.

[20] Werner, R.T. (1953) Interpretation of Magnetic Anomalies at Sheet-Like Bodies. Sveriges Geologiska Undersok, Series C, Arsbok, 6, 413-449.

[21] Ku, C.C. and Sharp, J.A. (1983) Werner Deconvolution for Automated Magnetic Interpretation and Its Refinement Using Marquardt's Inverse Modeling, Geophysics, 48, 754-774. http://dx.doi.org/10.1190/1.1441505

[22] Ku, C.C. (1977) A Direct Computation of Gravity and Magnetic Anomalies Caused by 2and 3-D Bodies of Arbitrary Magnetic Polarization by Equivalent-Point.

[23] GM-SYS. (1995) Gravity and Magnetic Modelling Version 3.6. Northwest Geophysical Association (NGA) Inc., Corvallis.

[24] Reid, J.M. and Granser, A.H. (1990) Magnetic Interpretation in Three Dimentions Using Euler Deconvolution. Geophysics, 55, 80-91. http://dx.doi.org/10.1190/1.1442774

[25] Hsu, S.-K. (2002) Imaging Magnetic Sources Using Euler's Equation. Geophysical Prospecting, 50, 15-25. http://dx.doi.org/10.1046/j.1365-2478.2001.00282.x

[26] Stavrev, P.Y. (1997) Euler Deconvolution Using Differential Similarity Transformations of Gravity or Magnetic Anomalies. Geophysical Prospecting, 45, 207-246. http://dx.doi.org/10.1046/j.1365-2478.1997.00331.x 
Submit or recommend next manuscript to SCIRP and we will provide best service for you:

Accepting pre-submission inquiries through Email, Facebook, LinkedIn, Twitter, etc. A wide selection of journals (inclusive of 9 subjects, more than 200 journals)

Providing 24-hour high-quality service

User-friendly online submission system

Fair and swift peer-review system

Efficient typesetting and proofreading procedure

Display of the result of downloads and visits, as well as the number of cited articles

Maximum dissemination of your research work

Submit your manuscript at: http://papersubmission.scirp.org/

Or contact ojg@scirp.org 